\title{
Ability of chitosan membrane from blood clam (Anadara granosa) shells to removal iron level $(\mathrm{Fe})$ in water
}

\author{
Nur Rafiqa Puspita Sari, Eri Iva Rustanti, Demes Nurmayanti, Ferry Kriswandana, Narwati \\ Department of Environmental Health, Poltekkes Kemenkes Surabaya, Indonesia
}

\begin{tabular}{|c|c|}
\hline Article Info & ABSTRACT \\
\hline Article history: & Clam shells are a food solid waste that increases and accumulates every day, \\
\hline Received Oct 6, 2020 & $\begin{array}{l}\text { causing environmental pollution. Clam shells (Anadora granosa) contain } \\
\text { chitin. Chitin can be processed into chitosan, which effective in absorbing }\end{array}$ \\
\hline Revised Feb 18, 2021 & heavy metals. To increase absorption, chitosan modified into a membrane. \\
\hline Accepted Mar 13, 2021 & $\begin{array}{l}\text { The purpose of this study was to analyze the membrane's ability of chitosan } \\
\text { waste from blood clam shells to reduce levels of iron in water. The design of }\end{array}$ \\
\hline Keywords: & $\begin{array}{l}\text { this study was pure experimentation. The object of research used was iron- } \\
\text { containing artificial water made from iron salt powder at a dose of } 4.50\end{array}$ \\
\hline Chitosan & $\mathrm{mg} / \mathrm{L}$. Variations of Chitosan concentration to the membranes manufacture \\
\hline Clam shell & $\begin{array}{l}\text { were } 1 \%, 2 \%, 3 \% \text {. Analysis of the data used was One Way Anova Test. } \\
\text { Chitosan characterization analysis using XR Diffraction showed that chitosan }\end{array}$ \\
\hline Iron level & was isolated from shells at peak angles at $17.99^{\circ}$ and $34.04^{\circ}$. The highest \\
\hline Membrane & $\begin{array}{l}\text { percentage of iron reduction was given by membranes with a chitosan } \\
\text { concentration of } 3 \% \text {, which have decreased of } 94 \% \text {. The results showed that } \\
\text { the membrane of blood shells chitosan can reduce iron levels in water and } \\
\text { can be an alternative material in the utilization of clamshell waste. The } \\
\text { membrane can be applied in simple water treatment filtration systems in the } \\
\text { community. }\end{array}$ \\
\hline
\end{tabular}

This is an open access article under the CC BY-SA license.

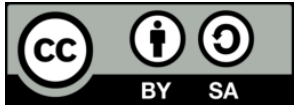

\section{Corresponding Author:}

Eri Iva Rustanti

Department of Environmetal Health

Poltekkes Kemenkes Surabaya

Pucang Jajar Tengah 56, Surabaya, Indonesia

Email: ivarust.eri@poltekkesdepkes-sby.ac.id

\section{INTRODUCTION}

Blood clam (Anadara granosa) are animals that belong to the type of mollusk or soft-bodied animals that have hard shells to protect their bodies. The large number of clams consumed by humans will produce waste from the clams namely clam shells. Clam shell which accumulate over time will disturb and pollute the environment. Every day the clam shell waste was dumped on the shore of Kenjeran beach, Surabaya, Indonesia. Every week there are around three tons of clam shells thrown away and piled up on the Kenjeran beach. Piles of waste shells on Kenjeran beach can destroy the aesthetics of the beach, cause bad smells and invite mice and flies that can be a source of disease. The field observations carried out on the shores of Kenjeran in October 2020, showed that the waste of clam shells accumulating on the shoreline are mostly clam shells from blood clam (Anadara granosa).

Clam shell waste has various contents which have high economic value, one of which is chitin. The nature of chitin which is non-toxic and easily degraded encourages chitin modification with the aim of optimizing the use and expanding the field of chitin application [1], [2]. Chitin that has been formed will be modified into chitosan [3]. Chitosan is obtained through the deacetylation of chitin which contains more than 
5000 units of glucosamine [4], [5]. With the presence of hydroxyl and amino groups along the polymer chain, chitosan can effectively absorb heavy metal ion cations [6], [7]. Chitosan is a hydrophobic compound, slightly soluble in $\mathrm{HCl}, \mathrm{HNO} 3$, and $\mathrm{H} 3 \mathrm{PO} 4$, insoluble in $\mathrm{H} 2 \mathrm{SO} 4$.

Chitosan is non-toxic, and easily biodegradable and polyelectrolyte [8]. To increase the absorption of chitosan against heavy metals, chitosan is modified in the form of membranes. In the process of making membranes, the addition of substances is often done to strengthen the structure of the membrane [9], [10]. Membranes are semipermeable, so they can hold certain compounds larger than the pore size of the membrane and pass other compounds with smaller sizes. The selective properties of this membrane can be used in the separation process [11], [12]. Modification of chitosan membrane is expected to produce membranes with better character, for example increasing membrane stability [13], [14], reducing the size of membrane pores so that the separation of molecules from a solution by membrane is more effective [15], [16]. The advantage of chitosan membrane separation compared to other separations is that there is no need for medium phase change, the process is fast, simpler, environmentally friendly, and can be reused [17].

This study aimed to analyze the ability of blood clam shells (Anadara granosa) waste as material for making chitosan membranes. Waste reduction by utilizing blood clam shells (Anadara granosa) as raw material for chitosan membrane. As well as to know the ability of chitosan membranes from blood clam shells in reducing levels of iron $(\mathrm{Fe})$ with variable chitosan concentration.

\section{RESEARCH METHOD}

This research was true experiment with pretest-posttest control group design. The object of research was artificial water containing iron $(\mathrm{Fe})$ which was made from ferric iron powder Ferri Chloride $\left(\mathrm{FeCl}_{3}\right)$ at a dose of $4.50 \mathrm{mg} / \mathrm{L}$. The membrane was prepared by adding chitosan powder (1gr, $2 \mathrm{gr}$, and $3 \mathrm{gr}$ ) to a $100 \mathrm{ml}$ mixture of acetic acid 1\%, 29ml poly vinyl alcohol (PVA) $25 \%$ solution , and $14 \mathrm{ml}$ poly ethylene glicol (PEG 400) solutions.

The process of making chitosan from shells consists of two stages, namely isolating chitin and converting chitin into chitosan. Chitin isolation was carried out by deproteination, demineralization and depigmentation processes. Deproteination, was done by adding $5003.5 \% \mathrm{NaOH}$ solution to $50 \mathrm{gr}$ of shellfish powder, stirring for two hours at $65^{\circ} \mathrm{C}$. Filtered the solution and neutralized it with aquadest. The solid obtained was dried in an oven at $80^{\circ} \mathrm{C}$ for two hours. Demineralization, $30 \mathrm{gr}$ of shell powder as a result of deproteination was added with $1 \mathrm{~N} \mathrm{HCl}$ solution of $300 \mathrm{ml}$ into the beaker glass. The mixture was heated at $40^{\circ} \mathrm{C}$ for 30 minutes, and then cooled. Filtered and neutralized the solids with aquadest, then dried at $80^{\circ} \mathrm{C}$ for two hours. Depigmentation, 20 grams of demineralized powder was added $200 \mathrm{ml}$ of $30 \% \mathrm{H}_{2} \mathrm{O}_{2}$ solution in a beaker, then heated for one hour at $50^{\circ} \mathrm{C}$, then cooled. Filtered and neutralized solids with aquadest. The solid obtained was dried at $90^{\circ} \mathrm{C}$ for two hours.

Transforming chitin into chitosan by Deacetylation process, $10 \mathrm{gr}$ of chitin powder from the depigmentation process were added with $50 \% \mathrm{NaOH}$ as much as $100 \mathrm{ml}$ in a beaker glass. Heat at a temperature of $95^{\circ} \mathrm{C}$ for two hours then cooled. Filtered and neutralized solids with aquadest until neutral then in the oven at $90^{\circ} \mathrm{C}$ for three times eight hours and the chitosan is ready to be tested. Chitosan membrane concentration variation were $1 \%, 2 \%$, and $3 \%$ and no membrane as a control with six times replication. Data were presented in tabular form and analyzed with One Way Anova Test.

\section{RESULTS AND DISCUSSION}

\subsection{Characterization of chitosan powder}

The results of examination of characterization of chitosan powder from blood clam shells (Anadara granosa) using the X-Ray diffraction (XRD) test can be seen in Figure 1. The characteristics of chitosan powder were tested for crystallinity using XRD test. Measurements were taken at an angle of 20. The XRD test results shown in Figure 1 showed the chitosan diffraction pattern. In the diffraction pattern there were peaks at an angle of $2 \theta$ which was equal to $17.99^{\circ}$ and the highest was $34.04^{\circ}$.

Chitosan powder diffractogram showed peaks at an angle of $2 \theta=17.99^{\circ}$ and the highest was $2 \theta=34.04^{\circ}$. The peak indicated the formation of chitosan. The characteristic peaks of chitosan appeared at $2 \theta$ $5-40^{\circ}$ reflecting the plane of $020,110,101$, and 130 . The peaks at around $2 \theta 24^{\circ}$ reflected the plane of 020 plane, while the peaks at $2 \theta 26^{\circ}$ reflected the plane of 110 , and the peaks at $2 \theta 29^{\circ}$ reflected the plane of 130 [18], [19]. XRD analysis results proved that chitosan has been successfully isolated from blood clam shells. 


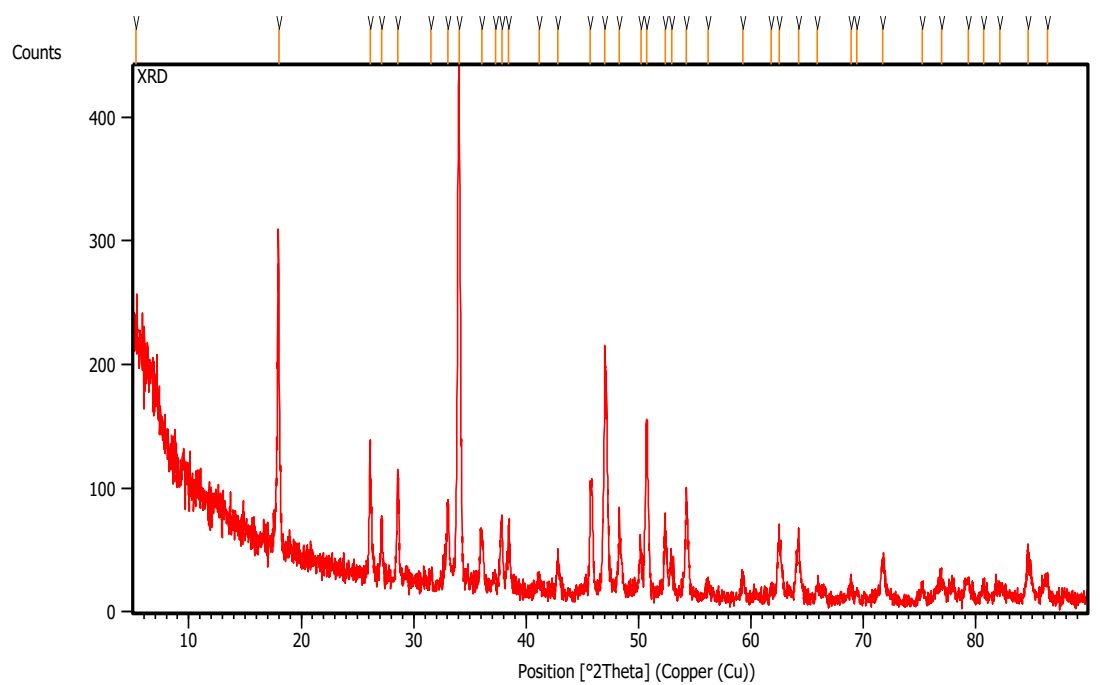

Figure 1. Chitosan powder XRD test results

\subsection{Chitosan membrane characterization}

The results of examining the characterization of chitosan membranes from blood clam shells (Anadara granosa) used scanning electron microscope (SEM) tests with the lowest and highest compressive strength values and the membranes that had the highest and lowest permeability values. SEM results on the membrane that have been carried out can be seen in Figure 2.

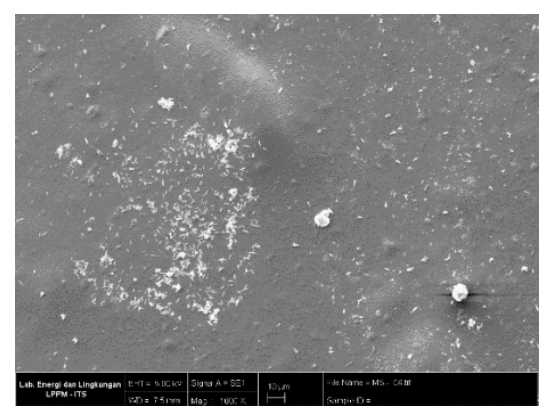

(a)

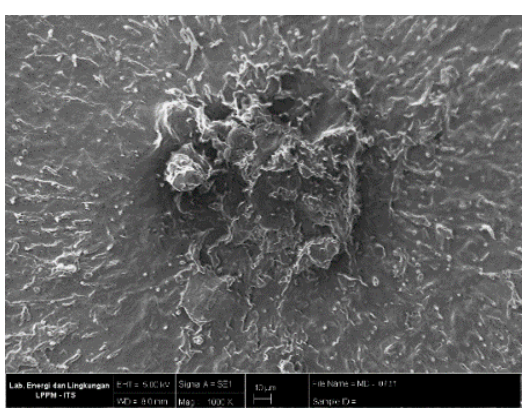

(b)

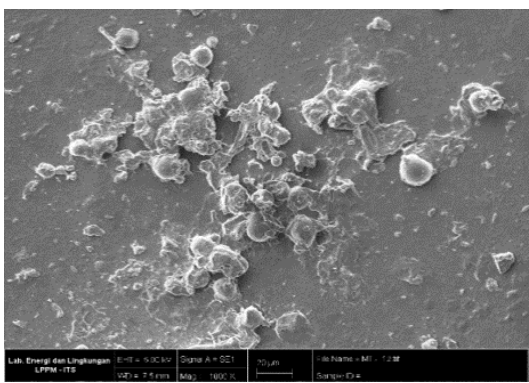

(c)

Figure 2. Chitosan membrane SEM test results (a) $1 \%$ concentration, (b) $2 \%$ concentration, (c) $3 \%$ concentration

Figure 2 shows that SEM test results of chitosan membranes show differences in membrane surface morphology. The membrane with a concentration of $1 \%$ chitosan showed a smoother and even surface. Meanwhile, the $2 \%$ and $3 \%$ concentrations of the membrane showed an uneven surface and there was a 
buildup of particles on the membrane surface. The greater the percentage of chitosan added, the denser the particle density which results in a smaller pore size of the membrane.

\subsection{Iron ( $\mathrm{Fe})$ levels in artificial water before and after the application of chitosan membranes}

The result of iron $(\mathrm{Fe})$ levels in artificial water before dan after the application using the chitosan membrane from blood clam shells can be seen in Table 1 .

Table 1. Iron $(\mathrm{Fe})$ level on artificial water before and after the application of chitosan membranes

\begin{tabular}{ccl}
\hline Concentration $(\%)$ & Average iron levels $(\mathrm{mg} / \mathrm{L})$ & Standard * \\
\hline Pretest & 4.5 & \\
Control & 4.45 & \\
1 & 2.78 & Max. 1 \\
2 & 1.24 & \\
3 & 0.30 & \\
\hline
\end{tabular}

Table 1 obtains the average iron (Fe) levels in artificial water with each application of chitosan membrane concentration to reduce iron $(\mathrm{Fe})$ levels in artificial water. From this table the value of iron $(\mathrm{Fe})$ that met the Permenkes No. 32 year 2017 was the treatment of chitosan application with a concentration of $3 \%$ in artificial water [21].

Table 1 shows that there were differences in iron $(\mathrm{Fe})$ levels in each water sample that has been applied. The application of chitosan membranes with variations in concentration had an influence on the iron content $(\mathrm{Fe})$ in artificial water. Chitosan can function as an absorber because it has amine and hydroxyl groups attached, therefore it can absorb iron $(\mathrm{Fe})$ in water. Chitosan membrane which is semipermeable are able to withstand greater species or as a filtration media. Ion Fe has a radius of $0.83 \AA$, while the pore membrane size of chitosan is 0.8 to $3.0 \mu \mathrm{m}$. Thus, the radius of the Fe metal ion was smaller than the size of the membrane, but it was likely that metal ions will enter and absorbed inside the membrane due to the irregular and multilayer membrane pore arrangement. Besides that, chitosan has the ability to absorb metals due to the presence of amino and hydroxyl groups, thus the membrane chitosan can occur filtration and adsorption events resulting in a better separation process [20], [22].

Iron retained in the membrane causes iron levels in artificial water to decrease. In the application of chitosan membrane concentration of 3\% it can make the levels of iron (Fe) meet Permenkes No. 32 of 2017 concerning environmental health quality standards and water health requirements for sanitation, swimming pools, solus per aqua and public baths where the maximum levels of iron $(\mathrm{Fe})$ is $1 \mathrm{mg} / \mathrm{L}$ [21]. The difference in iron content in each treatment showed that the process of separation and absorption that occured in water can reduce the existing iron content

\subsection{Analysis of difference in average decreased iron (Fe) levels in artificial water after application of chitosan membranes}

The results of the analysis of the difference in average and percentage decrease in iron $(\mathrm{Fe})$ levels in artificial water after application using chitosan membranes from blood clam shells can be seen in Table 2.

Table 2. Percentage of iron (Fe) removal in artificial water after application of chitosan membranes

\begin{tabular}{ccc}
\hline Concentration & Average removal iron levels & Percentage of removal \\
\hline $1 \%$ & $1.72 \mathrm{mg} / \mathrm{L}$ & $38 \%$ \\
$2 \%$ & $3.27 \mathrm{mg} / \mathrm{L}$ & $73 \%$ \\
$3 \%$ & $4.21 \mathrm{mg} / \mathrm{L}$ & $94 \%$ \\
\hline
\end{tabular}

Table 2 shows that presentation of decreased levels of iron $(\mathrm{Fe})$ in the sample variations in the concentration of chitosan membrane. The results of the average decrease in iron (Fe) showed that there has been a process of separation and absorption of Fe metal ions carried out by the chitosan membrane. The results obtained in this study indicated that the greatest decrease in iron $(\mathrm{Fe})$ content occured in water samples with a $3 \%$ membrane application namely a decrease of $94 \%$, while the smallest decrease occured in water samples with a $1 \%$ chitosan membrane application namely a decrease of $38 \%$. The addition of chitosan membrane concentration variation gave a great influence in decreasing levels of iron (Fe) artificial water. Table 2 shows that the higher the concentration of chitosan membrane, the higher the decrease in iron $(\mathrm{Fe})$ in water. The addition of chitosan in large quantities has an effect on increasing the tensile strength of the membrane. This condition shows that chitosan as a biopolymer tends to increase the compressive and tensile strength values [23]. Chitosan is able to form hydrogen bonds between chains to form a dense film [24], [25]. 
From the percentage decrease, it can be seen that the chitosan membrane can hold (Fe) ions in water. At a concentration of $3 \%$ the membrane was able to reduce $(\mathrm{Fe})$ ions as much as $94 \%$ and the remaining escaped cannot be held by the membrane. Chitosan membrane concentration can affect the density of membrane pores. The higher the concentration of chitosan in the membrane, the closer the pores of the chitosan membrane [26]. Besides that chitosan also has the ability to absorb metal ions [27], [28]. The ability of chitosan can bind metal ions due to high nitrogen content in the chitosan polymer chain. The nitrogen element is said to be an active group coordinating with metal cations [29], [30]. The difference in the average iron content $(\mathrm{Fe})$ shown in this study, where the iron content $(\mathrm{Fe})$ before which was higher than after treatment showed that the iron content in water can be reduced by the chitosan membrane. Besides having many benefits, chitosan membranes from blood shells also have weaknesses, chitosan membranes cannot be used too long, because they are easily saturated so that the process of absorbing metal is no longer optimal

\section{CONCLUSION}

The chitosan powder characterization results show that chitosan can be made from the basic ingredients of blood clam shells (Anadara granosa). Chitosan formed are white and odorless. Chitosan powder which is isolated from blood clam shells, has a peak diffractogram XRD test results at an angle of $2 \theta$ $17.99^{\circ}$ and $34.04^{\circ}$ and reflected fields $020,110,101,130$. In the membrane surface morphology, the greater the percentage of chitosan added, the denser the density, so that the pore size of the membrane becomes smaller. This can be seen through the results of the SEM test of the chitosan membrane with a concentration of $3 \%$ which shows the amount of particle buildup on the membrane surface. The results show that the membrane of blood shells chitosan can reduce iron levels in water and can be an alternative material in the utilization of clamshell waste. The membrane can be applied in simple water treatment filtration systems in the community.

\section{REFERENCES}

[1] S. Bahri, E. A. Rahim, and S. Syarifuddin, "Deacetylation Degree of Blood Shells Chitosan with Gradual Addition of NaoH," Kovalen, vol. 1, no. 1, pp. 36-42, 2015.

[2] A. R. Arif and H. Natsir, "Isolation of Chitin from White Shrimp Waste (Penaeus merguiensis) Enzymatically," Seminar Nasional Kimia, 2013, pp.10-16.

[3] A. A. Khan, "Effectiveness Of Blood Cockles ( Anadara Granosa ) Powder To Adsorb Cu ( Ii ) Ions In Water," Jurnal Teknik Lingkungan Universitas Islam Indonesia, vol. 1, no. II, pp. 1-10, 2016.

[4] E. J. Dompeipen and M. Kaimudin, "Isolation of Chitin and Chitosan from Shrimp Skin Waste," Maj. BIAM, vol. 12 , no. 1 , pp. 32-39, 2016.

[5] A. Artiningsih, "Making Chitosan From Crab Shell Using Microbes," Journal of Chemical Engineering, vol. 2, no. 1, pp. 30-35, 2017.

[6] T. L. Sung, L. M. Fwu, J. S. Yu, and S. S. Shin, "Equilibrium and kinetic studies of copper (II) ion uptake by modified wheat shells," Desalination and Water Treatment, vol. 44, no. 1-3, pp. 296-305, 2012.

[7] S. T. Pramesti, K. Khabibi, and N. B. A. Prasetya, "Application of the Utilization of Ascorbic Acid Modified Chitosan,” Jurnal Kimia Sains dan Aplikasi, vol. 15, no. 2, pp. 70-75, 2012.

[8] F. Savira and Y. Suharsono, "Optimization of Acetaldehyde Modified Crab Shell Chitosan as Pb (II) Metal Ion Adsorbent," Journal of Chemical Information and Modeling, vol. 1, no. 1, pp. 1689-1699, 2013.

[9] V. Vania, "Study Of Zinc ( Zn 2 + ) Metal Removal In Electroplating Wastewater By Using," Thesis, Institut Teknologi Sepuluh Nopember, 2016.

[10] S. Yunianti, Maharani, and D. Kartika, "Utilization of Chitosan-Silica to Reduce Pb (II) Ion Levels In Solution," Unesa Journal of Chemistry, vol. 1, no. 1, pp. 108-115, 2012.

[11] Z. M. Brilliantari, A. Shofiyani, and L. Destiarti, "Synthesis and Characterization of Ion Printed Chitosan Membrane on the Carbon (KTI-C) Surface to Increase the Permeselectivity of Fe (III) Ion,” J. Kimia Katulistiwa, vol. 6, no. 3,pp. 44-50, 2017.

[12] K. Ghasemzadeh, S. M. S. Tilebon, and A. Basile, "Chapter 20 - Membranes for NG separation processes: Recent Progress and Future Perspectives," Current Trends and Future Development on (Bio-) Membranes, Elsevier, ISBN. 978-0-12-817807-2, pp. 591-624, 2018.

[13] H. Rosalina, "Reduction of Heavy Metal Content from Metal Coating Industry Liquid Waste using Chitosan-PVA Composite Membrane," Journal of Chemical Information and Modeling, vol. 53, no. 9, pp. 1689-1699, 2019.

[14] I. F. Farha and N. Kusumawati, "The Effect of PVA on Morphology and Performance of Chitosan Membrane in the Separation of Rhodamine-B dye," Pros. Semin. Nas. Kim. UNEA, 2012, pp. 978-979.

[15] E. Supriyantini, B. Yulianto, A. Ridlo, S. Sedjati, and A. C. Nainggolan, "Utilization of Chitosan from Crab Shell Waste (Portunus pelagicus) as Lead Metal Adsorbent (Pb)," Journal Kelautan Tropis, vol. 21, no. 1, pp. 23-28, 2018.

[16] S. Muljani, K. A. Kusuma, L. Nofitasari, and A. R. Amalia, "Synthesis of chitosan silica membrane from sludge geothermal," Journal Teknik Kimia, vol. 13, no. 1, pp. 22-26, 2018. 
[17] K. Nita and T. Septiana, "Preparation and Ability Test of Chitosan Membranes as Ultrafiltration Membranes for the Separation of Rhodamine B Dyes," Molekul, vol. 7, no. 1, pp. 43-52, 2012.

[18] Zhang, Z, L. Chen, J. Ji, H. Y, and D. Chen, "Antibacterial Properties of Cotton Fabrics Treated with Chitosan, Textile Researh Journal," pp. 1103-1106, 2003.

[19] Fitrah Rama Dhony S., "Preparation of Chitin/Chitosan Composite Extracted from Crab Shells and Characterization," Thesis, Univ. Andalas, 2012.

[20] E. Sulistyawati, N. D. Wijaya, and Tantriyani, "Chitosan Membrane as Iron (Fe) Logan Adsorbent in Well Water in Chemical Engineering UPN 'Veteran' Yogyakarta," Prosiding Seminar Nasional Teknik Kimia, "Kejuangan," 2018, pp. 1-7.

[21] Minister of Health of the Republic of Indonesia, "The Indonesian Ministry of Health. Regulation of the Minister of Heath of the Repulic Indonesia Number 32 Year 2017 Concerning Environmental Health Standard Quality Standard and Water Health Requirements for Sanitation Hygiene Swimming Pools, Solus Per Aq," Peraturan Menteri Kesehatan Republik Indonesia, pp. 17-20, 2017.

[22] M. Khairuni, Z. Alfian, and H. Agusnar, "The Studi of Chitosan-CuO Composite's Application As Adsorbent in the removal of Fe, Mn, and Zn in Belawa River Water," Jurnal Kimia Mulawarman, vol. 14, no. 2, pp. 115-119, 2017.

[23] W. Setiani, T. Sudiarti, and L. Rahmidar, "Preparation and Characterization of Edible Film from Polybend of Starch Breadfruit-Chitosan," Journal Kimia Valensi, vol. 3, no. 2, pp. 100-109, 2013.

[24] E. Szymańska and K. Winnicka, "Stability of chitosan-A challenge for pharmaceutical and biomedical applications," Marine Drugs, vol. 13, no. 4, pp. 1819-1846, 2015.

[25] S. Ifuku, "Chitin and chitosan nanofibers: Preparation and chemical modifications," Molecules, vol. 19, no. 11, pp. 18367-18380, 2014.

[26] S. Ramadhanur and A. M. Sari, "Effect of Chitosan Concentration and Filtration Time of Chitosan Membrane on Decreasing Waste Detergent Phosphate Levels," Konversi, vol. 4, no. 1, pp. 40-52, 2015.

[27] D. A. Setiawan, B. D. Argo, and Y. Hendrawan, "Effect of concentration and membrane preparation on the characterization of chitosan membranes," J. Keteknikan Pertan. Trop. dan Biosist., vol. 3, no. 1, pp. 95-99, 2015.

[28] E. Noralia and D. K. Maharani, "Filtration Metal Ion Cr 6 + With Composite Chitosan Silica Membrane," Unesa J. Chem., vol. 2, no. 1, pp. 24-28, 2013.

[29] S. Ma'mun, Marhaenia Theresa, and S. Alfimonia, "The Use of Chitosan Membranes to Reduce Chrome MetalLevels in the Leather Tanning Industry Waste," Jurnal Teknologi Industri, vol. 22, no. 5, pp.367-371, 2016.

[30] N. Ghaemi, P. Daraei, and F. S. Akhlaghi, "Polyethersulfone nanofiltration membrane embedded by chitosan nanoparticles: Fabrication, characterization and performance in nitrate removal from water," Carbohydr. Polym., vol. 191, pp. 142-151, 2018. 